\title{
PENGARUH TRITERPEN TOTAL PEGAGAN (Centella asiatica (L) Urban) TERHADAP FUNGSI KOGNITIF BELAJAR DAN MENGINGAT PADA MENCIT JANTAN ALBINO (Mus musculus) YANG DIHAMBAT DENGAN SKOPOLAMIN
}

\author{
Herlina \\ Jurusan Kimia FMIPA, Universitas Sriwijaya, Sumatera Selatan
}

\begin{abstract}
Pegagan (Centella asiatica (L) Urban) has been described to posses CNS effects such as improving cognitive function, learning and memory. The aim of the research was to evaluate the effects of total triterpen's pegagan extract on cognitive functions as the learning and memory performance in male albino mice (Mus musculus) inhibited by scopolamine. The research design was Complete Randomized Design (RAL) - factorial on thirty six mice divided into 4 groups. One control group received only aquabidest (negative control). Three treatment groups received total triterpen $16 \mathrm{mg} / \mathrm{kg} \mathrm{BW}, 32 \mathrm{mg} / \mathrm{kg}$ BW orally and piracetam $500 \mathrm{mg} / \mathrm{kg} \mathrm{BW}$ by intra peritoneally (positive control) for 21 days. Data indicating learning and memory process of all subjects were obtained from onetrial passive avoidance test. Data were analyzed by two way ANOVA and BNT $(p<0,05)$. Result showed that total triterpen $32 \mathrm{mg} / \mathrm{kg} \mathrm{BW}$ had significantly prolonged the retention time compared to control group indicating improvement in cognitive function $(505,03$ second vs $-18,53$ second $)(\mathrm{p}<0,05)$ and it was not significantly different to piracetam 500 $\mathrm{mg} / \mathrm{kg} \mathrm{BW}$ group (505,03 second vs 522,48 second) (p>0,05). In conclusion, total triterpen from pegagan (Centella asiatica (L) Urban) improved learning ability and memory of male albino mice (Mus musculus) even though, it was inhibited by scopolamine.
\end{abstract}

Key words : Pegagan, cognitive function, passive avoidance test

\section{PENDAHULUAN}

Fungsi kognitif adalah kemampuan berpikir dan rasionalisasi, termasuk proses belajar, mengingat, menilai, orientasi, persepsi dan memperhatikan. Gangguan fungsi kognitif erat kaitannya dengan fungsi otak karena kemampuan untuk berpikir akan dipengaruhi oleh otak.

Gangguan fungsi kognitif adalah suatu gangguan fungsi otak berupa gangguan orientasi, perhatian, konsentrasi, daya ingat dan bahasa serta fungsi intelektual (Freidl et al., 1996). Menurut Kusisto et al., (1992), gangguan fungsi kognitif adalah suatu gangguan ke arah demensia yang diperlihatkan dengan adanya gangguan berhitung, bahasa, daya ingat semantik (kata-kata), dan pemecahan masalah (problem solving). Gangguan fungsi kognitif untuk jangka panjang jika tidak dilakukan pananganan yang optimal akan meningkatkan resiko demensia (Desmond, 1996).

Gangguan fungsi kognitif dapat diperbaiki oleh obat-obatan yaitu: obat nootropika (seperti pirasetam, piritinol, Ginkgo biloba dan Centella asiatica sudah diteliti oleh Gupta tahun 2003 yang dapat meningkatkan fungsi kognitif) dan antioksidan yang berfungsi untuk memelihara sel-sel saraf atau neuron yang rusak, contohnya Ginkgo biloba, mineral, magnesium dan kalsium.

Pegagan (Centella asiatica (L.) Urban) adalah tumbuhan herba yang sudah lama dimanfaatkan sebagai tanaman obat. Secara empirik dan ilmiah, pegagan terbukti mempunyai khasiat dalam menyembuhkan berbagai macam penyakit, antara lain untuk menyembuhkan sariawan, obat kusta, 
penurun panas, peluruh air seni, hipertensi, diabetes, anemia dan lain-lain. Penggunaan yang paling banyak akhirakhir ini adalah untuk menambah daya ingat (Winarto dan Surbakti, 2005).

Menurut Gupta \& Kumar (2003), Centella asiatica (L.) Urban dapat meningkatkan fungsi kognitif dan oksidatif stress yang diinduksi dengan streptozotocin secara intracerebroventricular pada tikus dengan penyakit Alzheimer. Centella asiatica (L.) Urban juga dapat meningkatkan fungsi kognitif dan oksidatif stress pada tikus normal. Ekstrak cair Centella asiatica (L.) Urban dapat meningkatkan fungsi kognitif pada dosis $200 \mathrm{mg} / \mathrm{kg} \mathrm{BB}$ dan $300 \mathrm{mg} / \mathrm{kg} \mathrm{BB}$. Menurut Chen et al. (2003), total triterpen dari Centella asiatica (L.) Urban dapat mempunyai aktivitas antidepressant.

Berdasarkan uraian diatas pegagan dapat meningkatkan fungsi kognitif, sedangkan perlakuan total triterpen pegagan terhadap fungsi kognitif belajar dan mengingat pada mencit jantan albino (Mus musculus) yang dihambat dengan skopolamin belum pernah diteliti, sehingga peneliti tertarik untuk melakukan penelitian tentang perlakuan total triterpen pegagan (Centella asiatica (L.) Urban) terhadap fungsi kognitif belajar dan mengingat pada mencit jantan albino (Mus musculus) yang dihambat dengan skopolamin.

\section{METODOLOGI PENELITIAN Pembuatan triterpen total pegagan}

Serbuk simplisia pegagan diekstraksi dengan cara sokletasi, sehingga didapatkan ekstrak kental pegagan. Ekstrak kental dikocok dengan akuades, biarkan dingin kemudian disaring. Filtrat hasil dipisahkan dan diambil endapannya. Endapan dikocok kembali dengan metanol kemudian disaring dan diambil filtratnya. Filtrat yang didapat dihilangkan klorofilnya dengan menambahkan arang aktif, diaduk kemudian biarkan sampai jernih, sesudah itu disaring. Filtrat yang didapat diuapkan kembali pelarutnya sehingga didapatkan triterpen total pegagan.

\section{Pembuatan sediaan dari bahan uji}

Triterpen merupakan senyawa yang kurang polar dan tidak larut dalam air. Untuk membuat total triterpen pegagan menjadi sediaan oral yang homogen maka dapat dibuat larutan dalam air dengan menambahkan surfaktan tween 80 .

\section{Prosedur Kerja}

Hewan uji dibagi menjadi 4 kelompok perlakuan dan masing-masing perlakuan dibagi lagi menjadi tiga sub kelompok yaitu :

- Perlakuan I akuabidest steril dengan skopolamin $0 \mathrm{mg} / \mathrm{kg} \mathrm{BB} ; 1,5 \mathrm{mg} / \mathrm{kg}$ $\mathrm{BB} ; 3,0 \mathrm{mg} / \mathrm{kg} \mathrm{BB}$.

- Perlakuan II dosis total triterpen pegagan $16 \mathrm{mg} / \mathrm{kg} \quad \mathrm{BB}$ dengan skopolamin $0 \mathrm{mg} / \mathrm{kg} \mathrm{BB} ; 1,5 \mathrm{mg} / \mathrm{kg}$ $\mathrm{BB} ; 3,0 \mathrm{mg} / \mathrm{kg} \mathrm{BB}$.

- Perlakuan III dosis total triterpen pegagan $32 \mathrm{mg} / \mathrm{kg} \quad \mathrm{BB}$ dengan skopolamin $0 \mathrm{mg} / \mathrm{kg} \mathrm{BB} ; 1,5 \mathrm{mg} / \mathrm{kg}$ $\mathrm{BB} ; 3,0 \mathrm{mg} / \mathrm{kg} \mathrm{BB}$.

- Perlakuan IV dosis pirasetam 500 $\mathrm{mg} / \mathrm{kg}$ BB dengan skopolamin 0 $\mathrm{mg} / \mathrm{kg} \mathrm{BB} ; \quad 1,5 \mathrm{mg} / \mathrm{kg} \mathrm{BB} ; 3,0$ $\mathrm{mg} / \mathrm{kg} \mathrm{BB}$.

Masing-masing subkelompok perlakuan terdiri dari 3 ekor mencit.

Pada perlakuan I, II dan III mencit diberi sediaan secara oral dan perlakuan IV mencit diberi sediaan secara ip selama 3 minggu, kemudian hari ke 22 dilakukan uji menghindar pasif pertama dimana mencit akan memasuki ruang gelap dan dihitung LT, setelah itu mencit diberi suntikan skopolamin secara ip, kemudian mencit dimasukan ke kandang. Setelah 24 jam dilakukan uji menghindar pasif kedua dan dihitung RT. 
Semua mencit diberi makan dan minum secukupnya dengan penerangan gelap dan terang diatur bergantian setiap 12 jam. Mencit dirumahkan secara individual dalam kandang. Untuk mengukur perilaku belajar dan mengingat dari semua mencit digunakan alat uji menghindar pasif modifikasi dari Jarvik dan Kopp (Jarvik and Kopp, 1967). Alat ini terdiri dari 2 ruangan, ruang kecil dan ruang besar. Ruang kecil $(25 \times 15 \mathrm{~cm})$ transparan dan diterangi dengan lampu 25 Watt setinggi $50 \mathrm{~cm}$ dari lantai berkawat yang disusun paralel. Ruang besar berupa kamar gelap berukuran $50 \mathrm{x}$ $50 \times 50 \mathrm{~cm}$ yang berlantai dari anyaman kawat paralel berjarak $1 \mathrm{~cm}$ antar sesamanya yang dialiri arus listrik $5 \mathrm{~mA}$. Kedua ruangan dihubungkan dengan sebuah pintu kecil $(10 \mathrm{~cm}$ tinggi, 7,5 $\mathrm{cm}$ lebar). Mencit yang akan diukur perilakunya diletakkan dalam ruangan kecil dan secara pasif diharapkan akan memasuki kamar gelap lewat pintu penghubung dan segera setelah masuk ke kamar gelap kakinya dikejutkan dengan arus listrik lemah yang dialirkan ke lantainya.

Pengukuran terdiri dari learning trial (LT) atau uji belajar dan retention trial (RT) atau uji retensi. Waktu antara uji belajar dan uji retensi adalah 24 jam, yang menggambarkan kemampuan mengingat jangka pendek dari objek. Waktu yang dibutuhkan oleh sampel mulai dari ruang kecil, lalu masuk ke dalam ruang gelap dicatat, kemudian diberi aliran listrik pada kakinya secara terkejut 1 kali 10 detik. Kemudian diberi suntikan skopolamin secara intraperitonial lalu dimasukkan ke dalam kandang. Setelah 24 jam dilakukan uji RT.

Untuk menilai perubahan pola perilaku belajar dan mengingat dilakukan uji menghindar pasif, di mana subjek setelah memperoleh obat sesuai dengan jadwal perlakuan, dilatih untuk pertama kali pada alat uji, lalu disangkarkan kembali dan setelah 24 jam kemudian dilakukan uji kembali seperti latihan pertama. Waktu "menunggu" mulai mengenal alat sampai subjek masuk secara pasif ke dalam ruang gelap disebut waktu belajar (learning time). Segera setelah masuk ruang gelap diberikan rangsang kejut pada kaki subjek. Waktu "menunggu" setelah subjek memperoleh retensi (tertunda selama 24 jam dalam sangkar masing-masing) sampai masuk kembali secara pasif ke dalam gelap disebut waktu retensi (retention time). Lama retensi, yaitu selisih waktu belajar dan waktu retensi diasumsikan sebagai kemampuan belajar dan mengingat

Waktu maksimal dalam pengukuran ini adalah 600 detik. Subjek dianggap mampu belajar dengan baik bila sebelum 60 detik sudah memasuki kamar gelap, sedangkan kriteria kemampuan mengingat dengan baik bila pada uji retensi subjek belum memasuki kamar gelap selama 600 detik. Subjek dinyatakan belajar dengan baik bila RT LT > 0. Variabel lama retensi yang menggambarkan kemampuan belajar dan mengingat adalah selisih RT - LT.

\section{HASIL DAN PEMBAHASAN}

Hasil uji fitokimia terhadap ekstrak pegagan (Centella asiatica (L) Urban) dapat dilihat pada tabel 1 .

Tabel 1. Hasil uji fitokimia ekstrak pegagan (Centella asiatica (L) Urban)

\begin{tabular}{|c|l|c|}
\hline No. & Metabolit skunder & Hasil \\
\hline 1. & Triterpenoid & ++ \\
\hline 2. & Steroid & - \\
\hline 3. & Alkaloid & - \\
\hline 4. & Flavonoid & - \\
\hline 5. & Saponin & + \\
\hline
\end{tabular}

Hasil uji fitokimia terhadap herba pegagan (Centella asiatica (L) Urban) menunjukkan bahwa pada bagian ini terdapat senyawa triterpenoid dengan kadar yang tinggi dan saponin. Hal ini 
sesuai dengan penelitian Morgan ti et al.(1999) dan Dalimartha (2004) bahwa kandungan kimia tanaman pegagan dan ekstraknya adalah senyawa triterpen saponisida pentasiklik seperti asiatikosida (ester dari asam asiatika dan trisakarida), thankunisida, isothankunisida madekassosida (ester asam madekasida da trisakarida), madasiatat sedangkan saponin-saponin minor seperti brahmosida, brahminosida, mesoinositol, centellosida dan centella saponin. Kandungan lainnya adalah karotenoid, garam-garam mineral seperti garam kalium, natrium, magnesium, kalsium, besi dan tanin. Dan menurut BPOM (2004), dari kandungan kimia tersebut senyawa triterpen saponisida dengan kadar terbesar adalah asiatikosida dan madekassosida.

\section{Pengaruh total triterpen pegagan (Centella asiatica (L) Urban) terhadap fungsi kognitif belajar dan mengingat}

Besarnya pengaruh total triterpen pegagan (Centella asiatica (L) Urban) terhadap fungsi kognitif belajar dan mengingat dapat dilihat dari lama retensi. Lama retensi adalah waktu retensi pada perlakuan pengulangan setelah 24 jam istirahat dikurangi lama waktu belajar pada hari pertama (RT - LT). Hasil lama retensi total triterpen pegagan setelah pemberian total triterpen pegagan (Centella asiatica (L) Urban) pada mencit jantan albino (Mus musculus) selama 21 hari secara oral dapat dilihat pada Tabel 2 dan Gambar 1.

Pemberian total triterpen pegagan (Centella asiatica (L) Urban) selama 21 hari secara oral pada mencit jantan albino (Mus musculus) menunjukkan hasil lama retensi yang diukur dengan uji menghindar pasif dan dapat dilihat pada tabel 2. Pada perlakuan kontrol tanpa skopolamin (tidak dilupakan) rata-rata lama retensinya 261,517 detik, dengan skopolamin (dilupakan) $1,5 \mathrm{mg} / \mathrm{kg}$ BB rata-rata lama retensinya 199,69 detik sedangkan dengan skopolamin $3,0 \mathrm{mg} / \mathrm{kg}$ BB rata-rata lama retensinya - 18,533 detik. Pada perlakuan kontrol didapat rata-rata lama retensinya menurun dengan bertambahnya skopolamin yang berarti bahwa dengan disuntikkannya skopolamin, mencit jantan albino tersebut benar-benar lupa karena pemberian skopolamin berfungsi supaya daya ingatnya berkurang.

Tabel 2. Lama retensi semua perlakuan terhadap fungsi kognitif belajar dan mengingat yang dihambat oleh berbagai dosis skopolamin. $(\mathrm{n}=3)$

\begin{tabular}{|c|c|c|c|c|}
\hline Perlakuan & $\begin{array}{l}\text { Skopolamin } \\
\text { (mg/kg BB) }\end{array}$ & $\begin{array}{l}\text { × LT } \\
\text { (detik) }\end{array}$ & $\begin{array}{l}\text { * RT } \\
\text { (detik) }\end{array}$ & $\begin{array}{c}\Delta(\mathrm{RT}-\mathrm{LT}) \\
(\text { detik })\end{array}$ \\
\hline \multirow[t]{3}{*}{ Kontrol } & 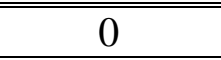 & 173.28 & 434.797 & $261.517 \quad b$ \\
\hline & 1,5 & 128.46 & 328.15 & 199.69 \\
\hline & 3,0 & 95.92 & 80.72 & $-18.533^{a}$ \\
\hline \multirow{3}{*}{$\begin{array}{l}\text { Pegagan } \\
16 \mathrm{mg} / \mathrm{kg} \mathrm{BB}\end{array}$} & 0 & 146.483 & 600.00 & $451.517^{\mathrm{cd}}$ \\
\hline & 1,5 & 58.883 & 526.433 & $467.55^{\mathrm{cd}}$ \\
\hline & 3,0 & 77.267 & 461.663 & $384.396^{c}$ \\
\hline \multirow{3}{*}{$\begin{array}{l}\text { Pegagan } \\
32 \mathrm{mg} / \mathrm{kg} \mathrm{BB}\end{array}$} & 0 & 105.813 & 600.00 & $494.187^{d}$ \\
\hline & 1,5 & 110.323 & 600.00 & $489.677^{d}$ \\
\hline & 3,0 & 94.97 & 600.00 & $505.03^{d}$ \\
\hline \multirow{3}{*}{$\begin{array}{l}\text { Pirasetam } \\
500 \mathrm{mg} / \mathrm{kg} \mathrm{BB}\end{array}$} & 0 & 84.127 & 600.00 & $515.873^{d}$ \\
\hline & 1,5 & 90.803 & 600.00 & $509.197^{d}$ \\
\hline & 3,0 & 77.523 & 600.00 & $522.477^{d}$ \\
\hline
\end{tabular}


Keterangan : Angka-angka yang diikuti oleh huruf yang berbeda menunjukkan perbedaan yang bermakna pada $\mathrm{p}<0,05$

$\mathrm{a}=$ Kontrol dengan skopolamin $3,0 \mathrm{mg} / \mathrm{kg}$ BB berbeda bermakna dengan semua perlakuan.

$\mathrm{b}=$ Kontrol dengan skopolamin $0 \mathrm{mg} / \mathrm{kg}$ BB tidak berbeda bermakna dengan kontrol dan skopolamin $1,5 \mathrm{mg} / \mathrm{kg}$ BB tetapi berbeda bermakna dengan kontrol dan skopolamin 3,0 $\mathrm{mg} / \mathrm{kg} \mathrm{BB}$, kelompok pegagan $16 \mathrm{mg} . \mathrm{kg} \mathrm{BB}$, kelompok pegagan $32 \mathrm{mg} / \mathrm{kg}$ BB dan kelompok pirasetam $500 \mathrm{mg} / \mathrm{kg} \mathrm{BB}$.

$\mathrm{c} \quad=$ Pegagan $16 \mathrm{mg} / \mathrm{kg}$ BB dengan skopolamin $3,0 \mathrm{mg} / \mathrm{kg}$ BB berbeda bermakna dengan semua kelompok perlakuan tetapi tidak berbeda bermakna dengan pegagan $16 \mathrm{mg} / \mathrm{kg} \mathrm{BB}$ dan skopolamin $0 \mathrm{mg} / \mathrm{kg}$ BB serta pegagan $16 \mathrm{mg} / \mathrm{kg} \mathrm{BB}$ dan skopolamin 1,5 mg/kg BB.

$\mathrm{d}=$ Pegagan $32 \mathrm{mg} / \mathrm{kg}$ BB tidak berbeda bermakna dengan pirasetam $500 \mathrm{mg} / \mathrm{kg} \mathrm{BB}$ dan pegagan $16 \mathrm{mg} / \mathrm{kg}$ BB dengan skopolamin $0 \mathrm{mg} / \mathrm{kg}$ BB dan skopolamin 1,5 mg/kg BB tetapi berbeda bermakna dengan pegagan $16 \mathrm{mg} / \mathrm{kg}$ BB dan skopolamin 3,0 mg/kg BB serta semua kontrol.

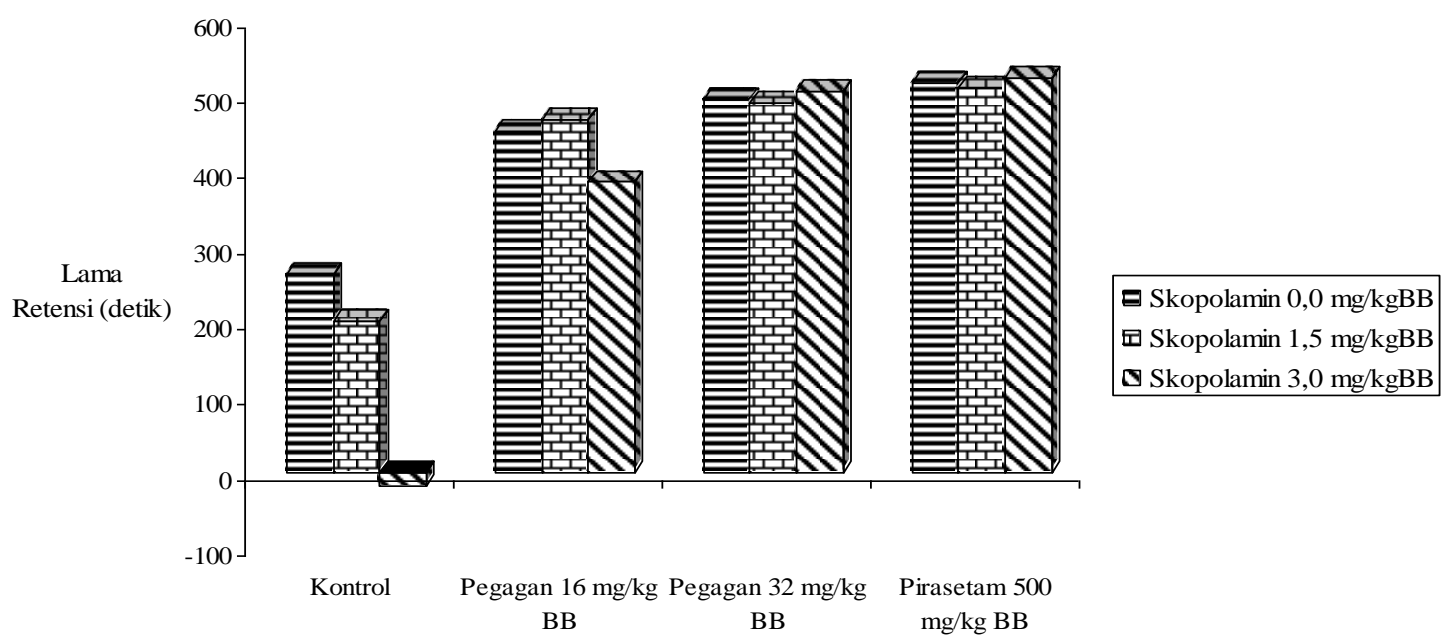

Gambar 1. Histogram lama retensi dari semua perlakuan yang dihambat oleh berbagai dosis skopolamin

Berdasarkan Tabel 2 dan Gambar 1 dapat dilihat, pada perlakuan kontrol semakin bertambah skopolamin maka rata-rata lama retensi yang didapat semakin menurun, pada pegagan 16 $\mathrm{mg} / \mathrm{kg} \quad \mathrm{BB} \quad$ semakin bertambah skopolamin maka rata-rata lama retensi yang didapat pada $0 \mathrm{mg} / \mathrm{kg}$ BB dan skopolamin $1,5 \mathrm{mg} / \mathrm{kg} \mathrm{BB}$ semakin bertambah sedangkan pada skopolamin $3,0 \mathrm{mg} / \mathrm{kg}$ BB rata-rata lama retensinya menurun, pada pegagan $32 \mathrm{mg} / \mathrm{kg} \mathrm{BB}$ semakin bertambah skopolamin maka rata-rata lama retensi yang didapat pada 0 $\mathrm{mg} / \mathrm{kg} \mathrm{BB}$ dan skopolamin $1,5 \mathrm{mg} / \mathrm{kg}$ BB semakin menurun sedangkan pada skopolamin 3,0 mg/kg BB rata-rata lama retensinya semakin menaik, sedangkan pada pirasetam $500 \mathrm{mg} / \mathrm{kg}$ BB sama dengan pegagan $32 \mathrm{mg} / \mathrm{kg}$ BB. Jika lama retensi menunjukkan waktu untuk terjadinya proses belajar dan mengingat yang berlangsung pada neurotransmisi kolinergik, maka pada tabel 2 dan gambar 6 terlihat bahwa terjadi peningkatan lama retensi dengan meningkatnya dosis pegagan, dan pegagan $32 \mathrm{mg} / \mathrm{kg} \mathrm{BB}$ hampir setara dengan pirasetam $500 \mathrm{mg} / \mathrm{kg} \quad \mathrm{BB}$ dibanding dengan kelompok kontrol. Semua mencit menunjukkan perpanjangan lama retensi berbeda bermakna dibandingkan dengan kelompok kontrol $(\mathrm{p}<0,05)$.

Efek total triterpen pegagan (Centella asiatica (L) Urban) terbukti mampu meretensi (mengendapkan) lebih lama suatu latihan yang dipelajari pada kelompok mencit yang dilupakan (dengan skopolamin) dimana pada 
pegagan $16 \mathrm{mg} / \mathrm{kg} \quad \mathrm{BB}$ dengan skopolamin $1,5 \mathrm{mg} / \mathrm{kg}$ BB rata-rata lama retensinya 467,55 detik; pegagan 16 $\mathrm{mg} / \mathrm{kg}$ BB dengan skopolamin 3,0 mg/kg BB rata-rata lama retensinya 384,396 detik; pegagan $32 \mathrm{mg} / \mathrm{kg} \mathrm{BB}$ dengan skopolamin $1,5 \mathrm{mg} / \mathrm{kg}$ BB rata-rata lama retensinya 489,677 detik; pegagan 32 $\mathrm{mg} / \mathrm{kg}$ BB dengan skopolamin 3,0 mg/kg BB rata-rata lama retensinya 505,03 detik, sedangkan pada mencit yang normal rata-rata lama retensinya kecil atau kontrol dengan skopolamin 1,5 $\mathrm{mg} / \mathrm{kg}$ BB lama retensinya 199,69 detik dan kontrol dengan skopolamin 3,0 $\mathrm{mg} / \mathrm{kg}$ BB lama retensinya $-18,533$ detik. Disini juga terbukti bahwa efek total triterpen pegagan (Centella asiatica (L) Urban) $32 \mathrm{mg} / \mathrm{kg} \mathrm{BB}$ hampir sama dengan pirasetam $500 \mathrm{mg} / \mathrm{kg}$ BB dimana rata-rata lama retensi yang dihasilkan hampir sama.

Berdasarkan hasil uji statistik terhadap lama retensi dengan uji analisis varian (ANOVA) dua arah $(\mathrm{p}<0,05)$ terdapat perbedaan bermakna, pemberian pegagan menunjukkan perpanjangan lama retensi berbeda bermakna dibandingkan dengan kelompok kontrol $(\mathrm{p}<0,05)$. Berdasarkan uji BNT, pemberian pegagan $16 \mathrm{mg} / \mathrm{kg} \mathrm{BB}$ dengan skopolamin $0 \mathrm{mg} / \mathrm{kg} \mathrm{BB}, 1,5 \mathrm{mg} / \mathrm{kg} \mathrm{BB}$ dan $3,0 \mathrm{mg} / \mathrm{kg} \quad \mathrm{BB}$ menunjukkan perbedaan bermakna dibandingkan dengan kelompok kontrol. Pegagan 16 $\mathrm{mg} / \mathrm{kg}$ BB dengan skopolamin 3,0 mg/kg BB menunjukkan perbedaan bermakna dibandingkan dengan pegagan $32 \mathrm{mg} / \mathrm{kg}$ $\mathrm{BB}$ dan pirasetam. Pegagan $32 \mathrm{mg} / \mathrm{kg} \mathrm{BB}$ dengan pirasetam $500 \mathrm{mg} / \mathrm{kg} \quad \mathrm{BB}$ menunjukkan perbedaan tidak bermakna dibandingkan dengan kelompok kontrol. Secara keseluruhan pegagan memberikan efek perpanjangan lama retensi secara bermakna dibandingkan dengan kelompok kontrol $(\mathrm{p}<0,05)$.

Lama retensi diukur dengan alat uji menghindar pasif. Walaupun uji menghindar pasif merupakan paradigma yang masih diperdebatkan, namun metoda ini sebenarnya cukup akurat karena dapat menilai parameter belajar dan penyimpanan memori (Matthies $\mathrm{H}$, 1980), sehingga metoda ini masih tetap digunakan untuk penelitian perilaku diseluruh dunia. Fungsi belajar dinilai dari waktu yang digunakan pertama kali mengenal lingkungan disekitar alat ini, sedangkan waktu retensi yang menggambarkan fungsi kognitif penyimpanan memori dinilai dengan respon sewaktu dilakukan uji ulangan dengan kondisi yang sama dan secara pasif membiarkan subjek menentukan dan memutuskan sendiri sesuai dengan fungsi kognitifnya untuk menghadapi uji kedua.

Uji menghindar pasif telah digunakan pula untuk menguji beberapa psikotropika seperti vinpocetine $(18-30$ $\mathrm{mg} / \mathrm{kg}$ p.o), apovincaminic acid (1 - 400 $\mathrm{mg} / \mathrm{kg}$ p.o), vincamine $(1-200 \mathrm{mg} / \mathrm{kg}$ p.o), vinconate (1 - $200 \mathrm{mg} / \mathrm{kg}$ p.o), aniracetam (1 - $300 \mathrm{mg} / \mathrm{kg} \quad$ p.o $)$, hydergine $(0,1-10 \mathrm{mg} / \mathrm{kg}$ p.o $)$ dan pemoline $((1-30 \mathrm{mg} / \mathrm{kg}$ p.o $)$ dengan hasil yang cukup sahih.

Untuk data parameter belajar dan mengingat yang diperoleh dari uji menghindar pasif didapat kesan bahwa total triterpan pegagan (Centella asiatica (L) Urban) menunjukkan efek yang berbeda secara bermakna dibanding dengan kelompok kontrol $(\mathrm{p}<0,05)$. Namun terdapat perbedaan bermakna antara total triterpen pegagan $16 \mathrm{mg} / \mathrm{kg}$ $\mathrm{BB}$ dan skopolamin 3,0 $\mathrm{mg} / \mathrm{kg} \quad \mathrm{BB}$ dengan total triterpen pegagan $32 \mathrm{mg} / \mathrm{kg}$ BB dan skopolamin $3,0 \mathrm{mg} / \mathrm{kg}$ BB, dimana rata-rata lama retensi dari total triterpen pegagan $16 \mathrm{mg} / \mathrm{kg} \mathrm{BB}$ dan skopolamin 3,0 mg/kg BB adalah adalah 384,40 detik jauh lebih kecil dibandingkan dengan rata-rata lama retensi triterpen total pegagan $32 \mathrm{mg} / \mathrm{kg}$ BB dan skopolamin 3,0 mg/kg BB (505, 03 detik). Diduga stimulasi fungsi kognitif oleh triterpen total pegagan 16 
$\mathrm{mg} / \mathrm{kg} \mathrm{BB}$ dengan skopolamin 3,0 mg/kg BB lebih lemah dibanding triterpen total pegagan $32 \mathrm{mg} / \mathrm{kg} \quad \mathrm{BB}$ dengan skopolamin 3,0 $\mathrm{mg} / \mathrm{kg}$ BB. Hal ini disebabkan oleh stimulasi asetilkolin oleh efek triterpen total pegagan $32 \mathrm{mg} / \mathrm{kg}$ BB lebih kuat dari triterpen total pegagan 16 $\mathrm{mg} / \mathrm{kg} \mathrm{BB}$, sehingga dapat mengatasi antagonis kompetitif dari skopolamin pada reseptor muskarinik. Oleh karena itu neurotransmisi kolinergik sentral walaupun dihambat oleh skopolamin masih mampu meningkatkan fungsi kognitif belajar dan mengingat ini. Efek triterpen total pegagan $(C$. asiatica $(\mathrm{L})$ Urban) konsisten pada dosis $32 \mathrm{mg} / \mathrm{kg}$ BB dimana efek intervensi antagonis kolinergik skopolamin nampak jelas dengan memanjangnya lama retensi. Dengan memanjangnya lama retensi, hal ini menunjukkan bahwa triterpen total pegagan $(C$. asiatica (L) Urban) dapat memperbaiki fungsi kognitif, dimana pengaruhnya sangat jelas pada dosis 32 $\mathrm{mg} / \mathrm{kg} \mathrm{BB}$ dan hampir setara dengan pirasetam $500 \mathrm{mg} / \mathrm{kg} \mathrm{BB}$.

Berdasarkan penelitian Gupta \& Kumar (2003), bahwa pegagan memiliki efek peningkatan kognitif dan efek antioksidan pada tikus normal dengan dosis $200 \mathrm{mg} / \mathrm{kg} \mathrm{BB}$ dan $300 \mathrm{mg} / \mathrm{kg}$ BB. Tikus yang diinjeksi dengan streptozotocin secara intracerebroventricular (i.c.v) yang dapat menginduksi stress oksidatif dan diobati dengan ekstrak cair pegagan menunjukan peningkatan fungsi kognitif. Penelitian ini menunjukkan bahwa ekstrak cair pegagan efektif mencegah kerusakan kognitif dan stress oksidatif yang disebabkan oleh streptozotocin secara intracerebroventricular pada tikus.

Berdasarkan penelitian Appa (1973), efek dari pegagan terhadap anak yang mengalami keterlambatan mental, setengah diberikan $500 \mathrm{mg}$ tablet dari pegagan kering (tumbuhan utuh) dan setengah placebo. Hasilnya menunjukkan bahwa anak-anak yang diberi tablet pegagan menunjukkan peningkatan yang signifikan dalam hal kerjasama, memori, konsentrasi, perhatian, kosa kata dan penyesuaian sosial.

Menurut penelitian Gorshkova et al.(1989) triterpen glikosida dapat menghambat $\mathrm{Na}^{+} \mathrm{K}^{+}$-ATPase pada otak tikus berarti triterpen total pegagan dapat menghambat $\mathrm{Na}^{+} \mathrm{K}^{+}$-ATPase sehingga terjadi depolarisasi dan kalsium didalam retikulum endoplasma meningkat, maka terjadi pacuan pelepasan asetilkolin terus-menerus. Pelepasan asetilkolin yang meningkat (berlangsung terusmenerus) akibatnya merangsang reseptor muskarinik terus-menerus, walaupun reseptor muskarinik dihambat oleh skopolamin, dengan adanya asetilkolin yang meningkat terus menerus maka reseptor muskarinik tetap meningkat pula sehingga neurotransmisi kolinergik sentral tidak terganggu dan terjadi peningkatan fungsi kognitif belajar dan mengingat.

Menurut Rao et al. (2005), pemberian ekstrak cair pegagan $(C$. asiatica (L) Urban) pada mencit yang baru lahir dapat meningkatkan kemampuan belajar dan mengingat setelah mencit tersebut berusia 6 bulan dan diikuti dengan peningkatan aktifitas enzim asetilkolinesterase. Dari penelitian ini diduga bahwa pelepasan asetilkolin meningkat karena terjadi depolarisasi akibat hambatan $\mathrm{Na}^{+} / \mathrm{K}^{+}$ATPase yang menyebabkan kalsium intrasel meningkat oleh triterpen total pegagan. Peningkatan asetilkolin tentu akan diikuti oleh peningkatan enzim asetilkolinesterase. Pelepasan asetilkolin yang meningkat (berlangsung terus-menerus) akibatnya memacu terus-menerus reseptor muskarinik sehingga akan memfasilitasi neurokolinergik diotak sehingga terjadi peningkatan fungsi kognitif. Dengan demikian fungsi kognitif belajar dan mengingat akan meningkat pula. Dengan demikian triterpen total pegagan $(C$. asiatica (L) Urban) dengan dosis 32 
$\mathrm{mg} / \mathrm{kg}$ BB dapat bermanfaat untuk meningkatkan fungsi kognitif belajar dan mengingat.

\section{KESIMPULAN DAN SARAN Kesimpulan}

Dari hasil penelitian ini dapat disimpulkan antara lain :

1. Triterpen total pegagan (C. asiatica (L) Urban) dengan dosis $32 \mathrm{mg} / \mathrm{kg}$ BB terbukti mempunyai efek meningkatkan fungsi kognitif belajar dan mengingat pada mencit jantan albino (Mus musculus) yang dihambat dengan skopolamin dan yang tidak dihambat dengan skopolamin sedangkan dengan dosis $16 \mathrm{mg} / \mathrm{kg}$ BB mempunyai efek yang lebih kecil.

2. Hambatan efek skopolamin dengan dosis 3,0 mg/kg BB terhadap pacuan fungsi kognitif belajar dan mengingat dapat diatasi hanya oleh triterpen total pegagan ( $C$. asiatica (L) Urban) dengan dosis $32 \mathrm{mg} / \mathrm{kg}$ BB

3. Efek triterpen total pegagan $(C$. asiatica (L) Urban) dengan dosis 32 $\mathrm{mg} / \mathrm{kg}$ BB hampir sama dengan pirasetam $500 \mathrm{mg} / \mathrm{kg} \quad \mathrm{BB}$ dalam meningkatkan fungsi kognitif belajar dan mengingat pada mencit jantan albino (Mus musculus).

\section{Saran}

1. Perlu dilakukan penelitian lanjutan untuk mengetahui senyawa yang lebih spesifik didalam triterpen total pegagan (C. asiatica (L) Urban) yang mempunyai efek meningkatkan fungsi kognitif belajar dan mengingat.

2. Perlu dilakukan penelitian untuk mengetahui pemberian triterpen total pegagan (C. asiatica (L) Urban) dengan dosis yang lebih besar dalam meningkatkan fungsi kognitif belajar dan mengingat.

\section{DAFTAR PUSTAKA}

Adams, R.D., M. Victor, A.H. Ropper. 1997. Principles of Neurology. $\left(6^{\text {th }}\right.$ Edition). McGraw-Hill Health Professions Division, New York.

Anonim. 2006. Gotu Kola, Medical \& Other Uses. (http://www.althealth. co.uk/services/info/supplements/ gotu kola1.php). Diakses 07 Desember 2006.

Appa Rao, M.V.R.et al. 1973. The Effecct of Mandookaparni (Centella asiatica) on The General Mental Ability (Medhya) of Mentally-Retarded Children. Journal of Indian Medicine. Aug : 9-12.

Badan POM, RI. 2004. Monografi Ekstrak Tumbuhan Obat Indonesia. (Volume I). Badan Pengawas Obat dan Makanan, Jakarta.

Chatterjee, T.K., A. Chakraborty, M. Pathak, and G.C. Sengupta. 1992. Effects of Plant Extract Centella asiatica (Linn) on Cold Restraint Stress Ulcer in Rats. Indian. J. Exp. Biology 30 (10): 889-891.

Chen, Y., Han T, Qin L, Rui Y \& Zheng H. 2003. Effect of Total Triterpenes from Centella asiatica on the Depression Behavior and Concentration of Amino Acid in Forced Swimming Mice. J. Zhong Yao Cai 26 (12) :870-3.

Darnis, F., L. Orcel, P.P. de Saint-Maur, and P. Mamou. 1979. Use of a titrated extract of centella asiatica (Linn) on cold restaint stress ulcer in rats. Indian J. Exp. Bio. 30 (10) : 889-891. 
Gupta, Y.K., and M.H.V. Kumar. 2003. Effect of Centella asiatica on Cognition and Oxidative Stress in an Intracerebroventricular Streptozotocin Model of Alzheimer's Disease in Rats. Clin Exp. Pharmacol. Physiol 30 : 336342.

Jarvik, M.E., and Kopp, R. 1967. An Improved One Trial Passive
Avoidance Learning Situation. Psychol. Rep. 21 : 221-4.

Kamaluddin, M.T., 2003. Regulasi Reseptor Muskarinik M1 Korteks Frontoparietalis dan Hippokampus Tikus Wistar oleh Pirasetam dan Piritinol dan Kaitannya dengan Proses Belajar dan Mengingat. Disertasi S3. Program Pascasarjana Universitas Padjadjaran Bandung. 